\title{
Thiethylperazine Maleate
}

National Cancer Institute

\section{Source}

National Cancer Institute. Thiethylperazine Maleate. NCI Thesaurus. Code C29497.

The maleate salt form of triethylperazine, a piperazine phenothiazine derivative and a dopamine antagonist used as antiemetic. Thiethylperazine blocks postsynaptic dopamine 2 (D2) receptors in the medullary chemoreceptor trigger zone (CTZ), thereby decreasing stimulation of the vomiting center in the brain. Peripherally, thiethylperazine blocks the vagus nerve in the gastrointestinal tract. In addition, this agent also shows antagonistic activities mediated through muscarinic receptors, $\mathrm{H} 1$-receptors, and alpha(1)-receptors. 